\title{
Symptomatic Rathke's cleft cyst with amyloid stroma
}

\author{
S. CONCHA, B. P. M. HAMILTON, ${ }^{1}$ J. C. MILLAN, \\ AND J. DONALD MCQUEEN \\ From Veterans Administration Hospital, Baltimore City Hospitals, \\ and The Johns Hopkins University School of Medicine, \\ Baltimore, Maryland, U.S.A.
}

SYNOPSIS A patient with panhypopituitarism and visual field defects due to a Rathke's cleft cyst is presented. These cysts are commonly found in random pituitaries examined at necropsy, but rarely produce symptoms. Subtle endocrine deficiencies, however, may now be uncovered more frequently with modern diagnostic techniques. An unusual and unreported feature of this cyst was an apudamyloid stroma. This would imply that cells derived from the neural crest participate in the formation of the cyst. Recognition of these cysts at the time of operation is important in avoiding confusion with pituitary adenomas and unnecessarily aggressive treatment.

Small cysts of Rathke's cleft which are asymptomatic are common (Bayouini, 1948; Shanklin, 1951). Occasionally, however, they may produce both neurological and endocrinological symptoms (Frazier and Alpers, 1934; Berry and Schlezinger, 1959; Fager and Carter, 1966; Giuffre and Gagliardi, 1968; Shuangshoti et al., 1970; Ringel and Bailey, 1972), when they may be mistaken clinically for chromophobe adenomas. This can lead to unnecessarily aggressive treatment.

Reported is a Rathke's cleft cyst associated with hypopituitarism and chiasmal compression. Histological studies of the cyst unexpectedly revealed an amyloid stroma, the implications of which are discussed.

\section{CASE HISTORY}

A 53 year old black male steelworker was admitted to a community hospital in August 1971, complaining of lethargy and loss of libido.

At examination he had the clinical features of hypothyroidism and hypogonadism without visual impairment. Skull radiography revealed a large sella with depression of the floor and thinning of the dorsum. No treatment was ordered and he was lost to follow up.

1 Address for reprint requests: Dr B. P. M. Hamilton, V.A. Hospital, 3900 Loch Raven Blvd., Baltimore, Maryland 21218, U.S.A. (Accepted 7 April 1975.)
In May 1972, he was admitted to the Loch Raveno 9 VA Hospital again with features of hypothyroidism and hypogonadism but no polyuria, headaches, or 0 visual disturbance. The main findings on examina $\frac{\mathbb{2}}{2}$ tion were as follows: height $172.7 \mathrm{~cm}$ (68 in.), weighto $100 \mathrm{~kg}(220 \mathrm{lb})$. He was well oriented, somnolent but $\bar{\epsilon}$ easily roused. His pulse was $55 / \mathrm{min}$ regular; blood pressure was $140 / 90 \mathrm{mmHg}$. His skin was cool ands. dry; the thyroid was not palpable. Ankle jerk re laxation was delayed. Beard, axillary and pubic hair were sparse. The prostrate was not palpable, testes were $2.5 \times 1.5 \mathrm{~cm}$ soft. Visual ability was (R) $20 / 25$ (L) $20 / 25$; fields were full on tangent screen examination.

ENDOCRINE STUDIES $^{2}$ (1) Thyroid Serum thyroxine (T4) level was $30.9 \mathrm{nmol} / \mathrm{l}(2.4 \mu \mathrm{g} / \mathrm{dl})$ (MurphyPattee, N. 5-13.7 $\mu \mathrm{g} / \mathrm{dl}) ; \mathrm{I}^{131}$ uptake at 24 hours was $5 \%$, after 10 u TSH intramuscularly it was $36 \%$; basal serum TSH (radioimmunoassay) was not detected, in response to TRH $50 \mu \mathrm{g}$ intravenously, it was not detected up to 20 minutes, reaching a peak of $12.4 \mu \mathrm{U} / \mathrm{ml}$ at 60 minutes. (2) Adrenal 24 hour urinary free cortisol was $276 \mathrm{nmol}(10 \mu \mathrm{g})$. (N. 16-71 $\mu \mathrm{g} / 24 \mathrm{hrs}$ ), with 40 units ACTH infused over eight hours it rose to $1167.5 \mathrm{nmol} / 24 \mathrm{hrs}(42.3 \mu \mathrm{g} / \mathrm{hr})$; plasma cortisol at 8 a.m. was $24.8 \mathrm{nmol} / 1(0.9 \mu \mathrm{g} / \mathrm{dl})$ (N. 9-20 $\mu \mathrm{g} / \mathrm{dl}$ ), after 25 units ACTH infused over five hours it rose to $690.0 \mathrm{nmol} / 1(25.0 \mu \mathrm{g} / \mathrm{dl}) ; 24$

2 Abbreviations: T4 - total thyroxine. TSH-thyroid stimulating hormone. RAI-radioiodine. TRH-thyrotrophin releasing hormone. ACTH-adrenocorticotrophic hormone. Compound S-11-deoxy cor782 


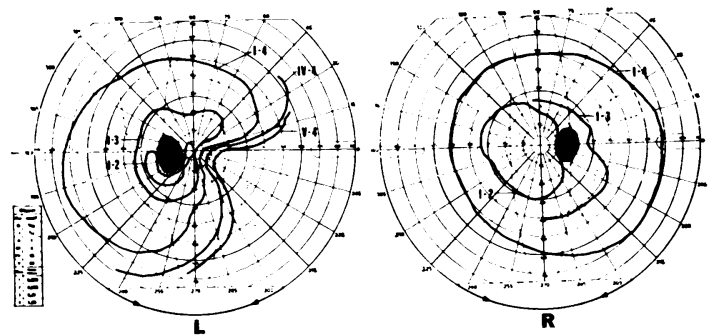

FIG. 1 Preoperative visual fields.

hours urinary tetra-hydro compound $\mathbf{S}$ (on the day of and the day after oral metyrapone $750 \mathrm{mg}$ four hourly for six doses) was 2.0 and $1.3 \mathrm{mg} / 24 \mathrm{hr}$ respectively. (3) Gonads Serum testosterone concentration was $150 \mathrm{ng} / \mathrm{ml}$ (radioligand assay), basal serum LH (radioimmunoassay) $<4 \mathrm{mIU} / \mathrm{ml}$; after oral clomiphene citrate $200 \mathrm{mg}$ /day for six days, LH was still $<4 \mathrm{mIU} / \mathrm{ml}$. (4) Growth hormone $(G H)$ Basal serum GH (radioimmunoassay) $1 \mathrm{pg} / \mathrm{ml}$, after intravenous, regular (soluble) insulin $0.1 \mathrm{U} / \mathrm{kg}$ body wt, blood glucose fell to $1.7 \mathrm{nmol} / 1$ (31 mg/dl); $\mathrm{GH}$ did not rise above $1 \mathrm{pg} / \mathrm{ml}$. (5) Posterior pituitary Average output of urine was 1.5-2.0 1/24 hr; serum sodium $138-141 \mathrm{mmol} / \mathrm{l}$; without fluids overnight, at 8 a.m. the serum osmolality was $288 \mathrm{mmol} / \mathrm{kg}$, urine osmolality $700 \mathrm{mmol} / \mathrm{kg}$.

Radiology of the skull showed an enlarged sella (20 mm long, $15 \mathrm{~mm}$ deep). Bilateral carotid angiograms were normal.

The patient was discharged on hormone replacement with oral L-thyroxine and cortisone acetate, and intramuscular testosterone. By August 1973 outpatient follow-up revealed a left visual field defect for
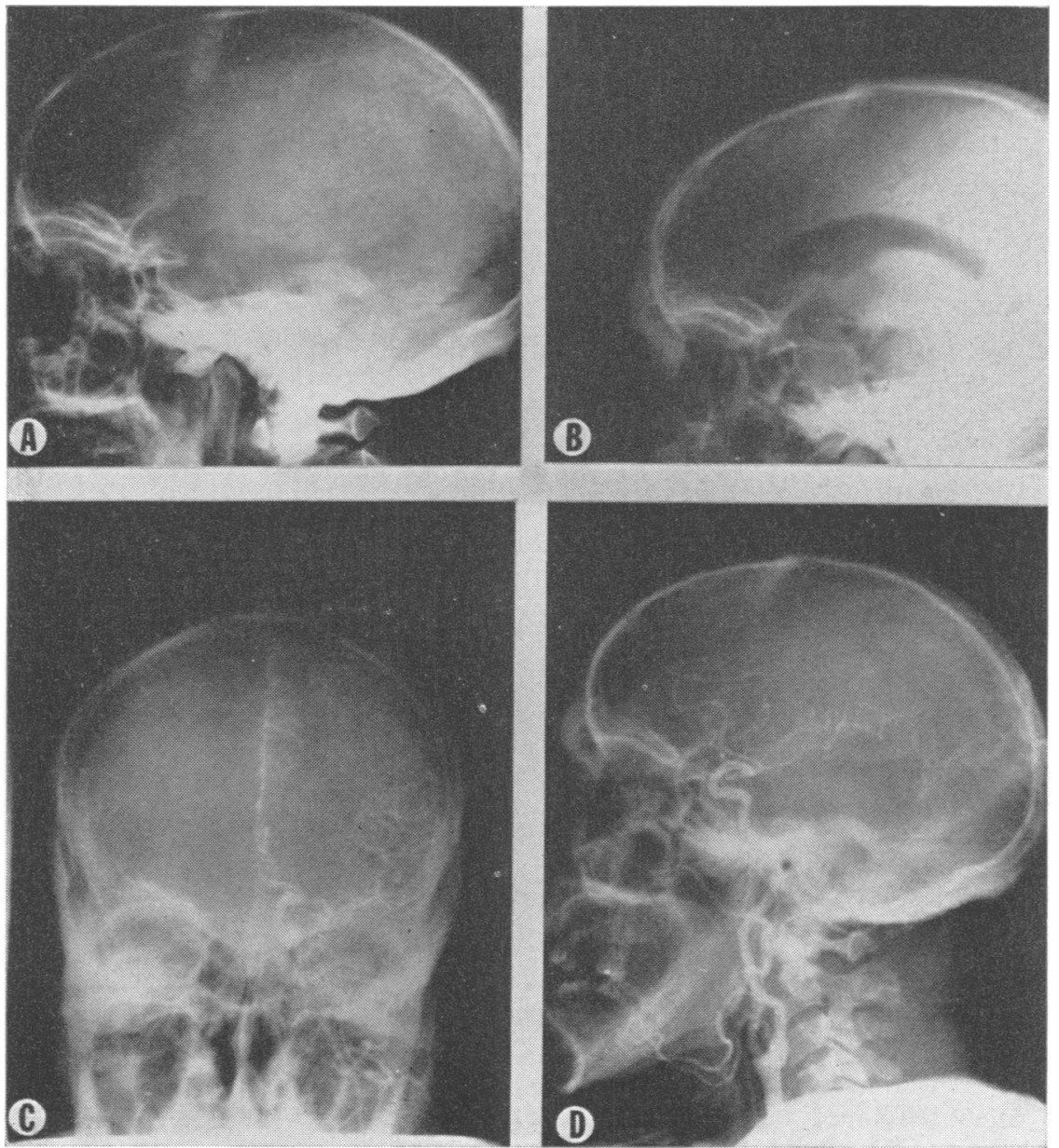

FIG. 2 Preoperative neuroradiology:

A. Lateral skull showing enlarged sella.

B. Pneumoencephalogram withquestionable suprasellar extension of tumour. $\mathrm{C}$ and D Normal carotid anteriogram. 


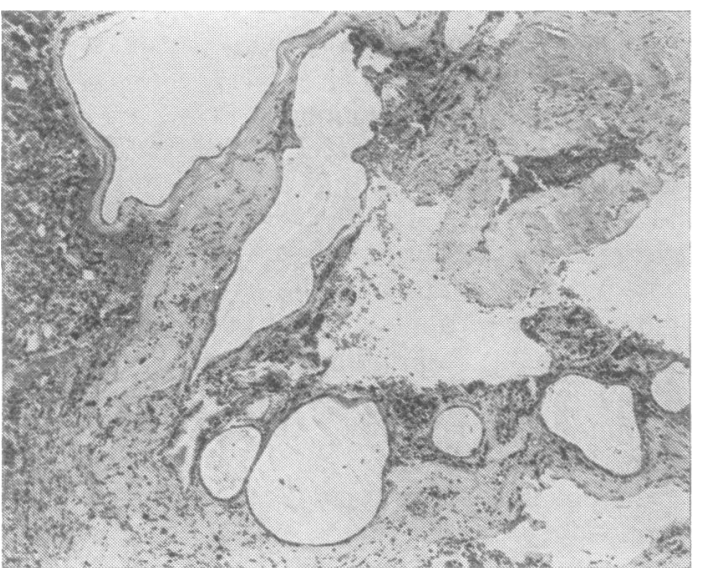

FIG. 3 Convoluted cyst replacing one-third of the hypophysis. $H$ and $E$ stain, $\times 48$.

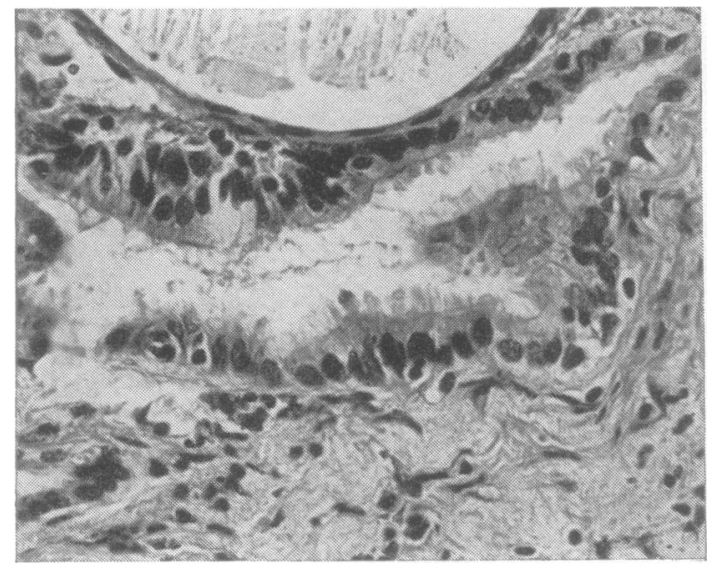

FIG. 4 Cyst lined by ciliated columnar cells. $H$ and $E$ stain, $\times 300$.

the first time (Fig. 1) with no additional signs. The sella now measured $24 \mathrm{~mm}$ long by $19 \mathrm{~mm}$ deep, the EEG was normal, and the pneumoencephalogram showed normal ventricles with no air in the sella but questionable suprasellar extension of a tumour mass (Fig. 2). Right frontal craniotomy was performed with the presumptive diagnosis of a pituitary adenoma. At operation a large encapsulated and apparently solid intrasellar tumour was found compressing both optic nerves. This was removed completely.

Postoperatively the patient developed partial diabetes insipidus with 24 hour urine volumes of 4-5 litres. The maximal urinary osmolality after dehydration was $350 \mathrm{~m}$ osmol $/ \mathrm{kg}$, promptly rising to $512 \mathrm{~m} \mathrm{osmol} / \mathrm{kg}$ with aqueous pitressin injected subcutaneously. This polyuria was initially well controlled with a combination of chlorpropamide and clofibrate, but cleared spontaneously after about nine months. The preoperative visual field defect was only partially corrected.

PATHOLOGY The specimen consisted of multiple pieces of soft tissue weighing approximately $0.5 \mathrm{~g}$. No gross cyst was identified.

Microscopically, one-third of the hypophysis was replaced by a convoluted cyst (Fig. 3). This was lined by simple cuboidal epithelium with occasional patches of ciliated columnar cells (Fig. 4). PAS positive, diastase resistant, and mucicarmine positive material was present intracellularly and in the cystic cavity which appeared distended and occasionally ruptured into a fibrous stroma. This fibrous stroma showed areas of homogeneous acidophilic material that stained positively for amyloid with Congo Red, by bright and polarized light. Thioflavine $\mathrm{S}$ staining was also positive (Fig. 5). Histochemical staining for tryptophan and tyrosine (Pearse, 1972) was negative. $\frac{0}{0}$.

A rim of compressed but entirely normal anterior $\stackrel{\infty}{\mathbb{N}}$ lobe of the gland and some remnants of the posterior $\frac{\rho}{\mathrm{D}}$ 음 lobe were identified. The exact relations of the cyst $\varrho-$ to the stalk could not be determined. The gross $?$ impression of solid tumour was probably caused by the prominent fibrous stroma.

\section{DISCUSSION}

Cysts of Rathke's cleft are found in 13-22\% of randomly examined pituitary glands (Bayouini, 1948; Shanklin, 1951); clinically detectable cysts,

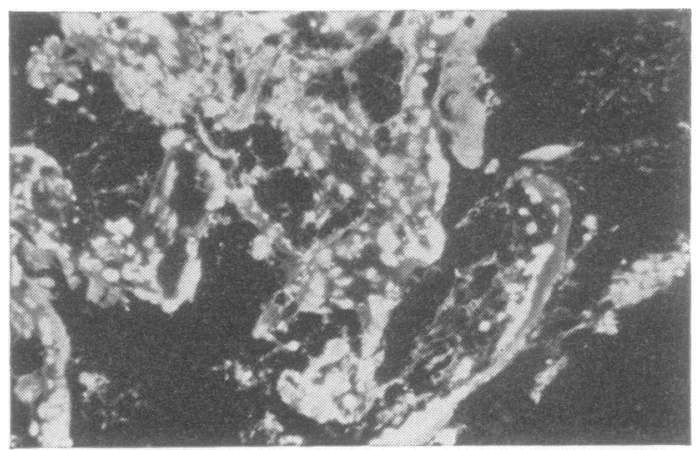

FIG. 5 Positive fluorescence of stroma. Thioflavine $S$, $\times 64$. 
however, are rare with only 30 odd cases reported and only 18 of these removed surgically. These cases produced asymptomatic enlargement of the sella turcica, or suprasellar symptoms such as headache and visual field defect, and endocrine dysfunction (Berry and Schlezinger, 1959).

This patient had sellar enlargement, visual field defects, and endocrine abnormalities which had remained quiescent for a period of years and then deteriorated, possibly due to cyst enlargement. Detailed endocrine studies are not available in the literature largely because the reported cases were studied before modern diagnostic techniques were available. Subtle partial hypopituitarism, therefore, may be more common with these cysts than is realized. The clinical impression of hypogonadism and hypothyroidism in our case was confirmed by the low serum testerostone and T4 and the low RAI uptake at 24 hours. A pituitary lesion was implicated as the cause by the low baseline $\mathrm{LH}$ which failed to rise with clomiphene stimulation (Bardin et al., 1967), and by the undetectable basal TSH levels which rose subnormally after TRH (Fleischer et al., 1970), while the RAI uptake did respond briskly to exogenous TSH. Along with these lesions, the presence of growth hormone deficiency indicated by the lack of response to insulin hypoglycaemia (Rabkin and Frantz, 1966) was expected. There were no clinical signs, however, of the secondary hypo-adrenalism, demonstrated by the low baseline steroids which rose with exogenous ACTH, and the subnormal tetrahydro compound $\mathrm{S}$ response to metyrapone (Liddle et al., 1959). Preoperatively water metabolism was normal, but the patient developed partial diabetes insipidus immediately after operation, achieving on deliberate dehydration a maximum urinary osmolality of $512 \mathrm{~m}$ osmol $/ \mathrm{kg}$ (Miller et al., 1970). This was presumably due to pituitary stalk damage at the time of operation, and had disappeared after nine months.

The prognosis for Rathke's cleft cysts is in general excellent. Characteristically, the disease progresses slowly and may remain stable for long periods of time (as in this case). The current therapy advocated is drainage with liberal opening of the wall (Fager and Carter, 1966) and only two recurrences have been reported (Ringel and Bailey, 1972). Therefore, before complete removal of any pituitary tumour is performed initial biopsy and examination of a frozen section is advocated to exclude this benign condition.

Histopathologically, the presence of ciliated columnar epithelium, forming cyst-like spaces with mucin material intracellularly and in the contents of the cyst, is diagnostic of so-called Rathke's cleft cysts (Berry and Schlezinger, 1959).

The embryological origin is controversial. The most commonly held view is that the cysts derive from Rathke's pouch epithelium (Frazier and Alpers, 1934; Shanklin, 1951; Berry and Schlezinger, 1959; Fager and Carter, 1966; Giuffre and Gagliardi, 1968; Ringel and Bailey, 1972), but the possibility that some may take origin from neuroepithelium cannot be easily rejected (Shuangshoti et al., 1970).

An unexpected finding in the present case was amyloid deposition in relation to the cyst. This is apparently rare. A solitary previous case report was found where amyloid was described in a chromophobe adenoma following radiation therapy in a dosage of 4,500 rads (Barr and Lampert, 1972). Amyloid may also occur in the pituitary in primary familial amyloidosis with polyneuropathy (Portuguese type) (Lampert, 1968). There was no evidence of this condition in our patient.

The amyloid we describe stained negatively for tryptophan and tyrosine. This is a feature of 'apudamyloid' distinguishing it from the more common 'immunamyloid' (Pearse, 1972) associated with abnormal immunoglobulin production. Apudamyloid is known to occur in a select group of endocrine tumours including medullary carcinoma of the thyroid, islet cell tumours of the pancreas, pheochromocytoma, foregut carcinoids, and carotid body tumours (Lampert, 1968; Pearse, 1969, 1974). 'These tumours have similar staining properties, histochemistry and histology. Furthermore, they have the potential for peptide hormone production and apudamyloid may represent fragments of these peptides (Pearse, 1972). There is now strong evidence that these close relationships are explained by a common origin of the cells involved from the primitive neural crest (Weichert, 1970).

Our findings therefore suggest that neural crest cells may participate in the development of Rathke's cleft cysts. Alternatively the apudamyloid may represent retained peptide hormone 
products from the compressed adjacent anterior pituitary. Here the ' $c$ ' and ' $m$ ' cells producing $\mathrm{ACTH} / \mathrm{MSH}$ could be implicated since they are also considered to be neural crest derivatives (Pearse, 1974).

We are grateful to Dr Rafael Garcia for advice on the pituitary histology.

\section{REFERENCES}

Bardin C. W., Ross, G. T., and Lipsett, M. B. (1967). Site of action of clomiphene citrate in men: a study of the pituitary-Leydig cell axis. Journal of Clinical Endocrinology, 27, 1558-1564.

Barr, R., and Lampert P. (1972). Intrasellar amyloid tumor. Acta Neuropathologica (Berl.), 21, 83-86.

Bayouini, M. L. (1948). Rathke's cleft and its cysts. Edinburgh Medical Journal, 55, 745-749.

Berry, R., and Schlezinger, N. (1959). Rathke-cleft cyst. Archives of Neurology, 1, 48-58.

Fager, C. H., and Carter, H. (1966). Intrasellar epithelial cysts. Journal of Neurosurgery, 24, 77-81.

Fleischer, N., Burgus, R., Vale, W., Dunn, T., and Guillemin, R. (1970). Preliminary observations on the effect of synthetic thyrotropin releasing factor on plasma thyrotropin levels in man. Journal of Clinical Endocrinology, 31, 109112.

Frazier, C. H., and Alpers, B. (1934). Tumors of Rathke's cleft. Archives of Neurology and Psychiatry, 32, 973-984.

Giuffre, R., and Gagliardi, F. M. (1968). Unusual hypophyseal tumor of Rathke's cleft origin. Neurochirurgia, 11, 81-89.

Lampert, P. W. (1968). Amyloid and amyloid like deposits. In Pathology of the Nervous System, pp. 1116-1117.
Edited by J. Minkler. McGraw-Hill: New York.

Liddle, G. W., Estep, H. L., Kendall, J. M., Jr, Williams, W. C., Jr, and Townes, A. W. (1959). Clinical application of a new test of pituitary reserve. Journal of Clinical Endocrinology, 19, 875-894.

Miller, M., Dalakos, T., Moses, A. M., Fellerman, H., and Streeten, D. H. T. (1970). Recognition of partial defects in antidiuretic hormone secretion. Annals of Internal Medicine, 73, 721-729.

Pearse, A. G. (1969). The cytochemistry and ultrastructure of polypeptide hormone producing cells of the APUD series and the embryologic, physiologic and pathologic implications of the concept. Journal of Histochemistry and Cytochemistry, 17, 303-313.

Pearse, A. G. (1972). Genesis of APUD amyloid in endocrine polypeptide tumors: Histochemical distinction from immunamyloid. Virchows Archiv für Zell Pathologie, 10, 93-107.

Pearse, A. G. (1974). The APUD concept and its implication in pathology. In Pathology Annual, pp. 24-41. Edited by Sheldon C. Sommers. Appleton-Century-Crofts: New York.

Rabkin, M. T., and Frantz, A. (1966). Hypopituitarism: A study of growth hormone and other endocrine functions. Annals of Internal Medicine, 64, 1197-1207.

Ringel, S., and Bailey, T. (1972). Rathke's cleft cyst. Journal of Neurology, Neurosurgery, and Psychiatry, 35, 693-697.

Shanklin W. H. (1951). The incidence and distribution of cilia in the human pituitary with a description of microfollicular cysts derived from Rathke's cleft. Acta Anatomica Scandinavica, 11, 361-382.

Shuangshoti, S., Netsky, M., and Nashold, B. (1970). Epithelial cysts related to the sella turcica. Archives of Pathology, 90, 444-450.

Weichert, R. F. (1970). The neural ectodermal origin of peptide secreting endocrine glands. American Journal of Medicine, 49, 232-241. 